\title{
Technical and Economical Evaluation of a Fresh-Water Production from Zero-Wastewater Reverse Osmosis System: A Feasibility Study in Jordan
}

\author{
Tarek Qasim ${ }^{1}$, Mohammed Said Obeidat ${ }^{1}$, Hazem Smadi $^{1}$ \\ ${ }^{1}$ Industrial Engineering Department, Jordan University of Science and Technology, Jordan \\ Correspondence: Tarek Qasim, Industrial Engineering Department, Jordan University of Science and Technology, Irbid \\ 22110, Jordan.
}

$\begin{array}{lcc}\text { Received: February 3, } 2018 & \text { Accepted: February 22, } 2018 \quad \text { Online Published: March 13, } 2018 \\ \text { doi:10.5539/res.v10n2p53 } & \text { URL: https://doi.org/10.5539/res.v10n2p53 }\end{array}$

\begin{abstract}
Jordan endures a shortage of fresh drinking water. Thus, there is a wide use of reverse osmosis (RO) units at homes and industrial zones. Zero wastewater, which is a modified reverse osmosis system, is developed and evaluated to overcome the problem of limited water. In Jordan, for example, Petra Company for Water Treatment Systems was established to mass-produce the newly modified RO units. In this study, a feasibility study is conducted to evaluate the technical and economical aspects of mass production of the new RO systems. With increasing future demand for fresh water, it is expected that the introduction of the new system to regional countries would save huge amounts of water. Additionally, good economical impacts will be achieved as a net profit to the newly established company. This expected extra profit would be set the base for further development to the modified RO system, such as introducing a compact multistage filtration unit. Results of the feasibility study showed a huge amount of water saving per annum estimated by 4.5 million cubic meter. In addition, a half million of Jordanian Dinar (JD) of a net annual profit attained at the current demand of RO units in Jordan.
\end{abstract}

Keywords: Reverse osmosis, Zero wastewater, Control unit, Jordan

\section{Introduction}

Jordan is a country with limited water resources, and it is classified as the poorest country in the region with water resources, because most of its territories are located in dry areas or semi-arid. In addition to the scarcity of annual rainfall in Jordan. Where the average rainfall in good seasons about 8.5 billion cubic meters; of which $92 \%$ evaporate, the remaining is up to 900 million cubic meters, part of which is moving to natural feeding of underground water and 600 million cubic meters left annually to flow across the plains and valleys (Ministry of Water and Irrigation, Jordan, website, 2018). Jordan large deficit of water exceeds 500 million cubic meters per annum and accompanied by an increase in water needs annually by an average of 4-6\% (Qasim et al., 2016). Causes of this increase are related to the increase in population, economy, agricultural and commercial growth, which has put extra pressure on the demand of the needed fresh water supply. In addition, Jordan is currently hosting a huge number of refugees, which leads to additional increase of water needs. By March 2017, and according to the Jordanian government's published figures, there are about 1.3 million Syrian refugees in Jordan accumulating about $20 \%$ of the Jordanian population (Ghazal, M. 2017). Increasing refugee number will definitely increase the need of water or at least a better utilization of water filtration process. This limitation of water resources has forced the Jordanian government to consider this problem as a first priority, especially when the number of refugees that Jordan host increases.

Recently, reverse osmosis technology has been the most commercially applied systems in several countries for producing fresh water because of its improved performance (Chaoa \& Liangb. 2008). In addition, reverse osmosis desalination units are preferred choice to be used in homes and industry. Membrane fouling and high operating cost in terms of reject water rate raise more uncertainties of its wide range usages at homes and industrial settings. Due to shortage of water resources for domestic use, saving the rejected saline water that is rejected from RO systems has become an essential concern worldwide (Middle East Desalination Research Centre. 2009).

Several studies have focused on water quality for drinking water using chemical absorbents to treat the saline water (Zaleschi et al., 2013, Khana et al., 2013, Fanga \& Duranceau, 2013). The effect of seawater temperature and seasonal changes on seawater desalination using RO membrane systems examined by several studies (Sassi \& Mujtaba, 2012, Young et al., 2010). Avlonitis studied the cost of cubic meter of fresh water that is produced by small-size RO desalination plants in remote parts of Greek islands for a period of three years, his study aimed to improve productivity 
using data acquisition and automation approach in remote area. Avlonitis concluded that in remote areas running low-cost RO plants improves work force productivity (Avlonitis, 2002). Middle East Desalination Research Center (MEDRC) funded a research project in the Middle East and North Africa (MENA) regions to develop zero-waste small RO units by utilizing the use of water softeners to remove salts from municipal water systems before distribution municipal water to homes. The objective was to make the RO units that are used at homes to operate more effectively (Middle East Desalination Research Centre. 2009). As can be seen, most of the research performed to optimize the RO system looked on the performance of the individual aspects of the system to enhance the quality of the produced water (Zhang et al., 2011, Mostafa \& El-Aassar, 2013).

Fresh water demand has expanded rapidly in the last decades. In addition to the Middle East region, the Arabian Gulf Region that is close to Jordan has the greatest potential for RO system use. Both, the rapid growth in population and the shortage of drinking water resources at the Arabian Gulf region make this region of great potential market for new desalination equipment. In addition, the countries around the Mediterranean Sea will experience the largest growth rate in population, which leads to extra demand on fresh water (Fritzmann ae al., 2007, Kolodziejski \& Gasson, 2005). Jordan and Arabian Gulf region countries suffer from a high water stress index (higher than 40\%) (Al-haj Alia et al., 2013). In these countries desalination production from RO system exceeds $11 \%$ (Lauren et al., 2009).Typical RO systems installed at homes have very high rejection rate - water wasted to drain. This results in huge amount of wasted water.

A new modified reverse osmosis (RO) water treatment system with $100 \%$ water recovery is needed very urgently to serve the deteriorating water situation in Jordan and neighboring countries. One of these systems is produced by Petra for Water Treatment Systems Company that is located in Jordan. The new system was developed in response to the necessities of finding solutions to contribute rationalization in consumption of water and to alleviate the problem of water shortage that is suffered by many countries worldwide, particularly Jordan (Qasim et al., 2016).

This paper presents a feasibility study of producing a low recovery rate of RO system by developing a newly modified RO system built at Petra for Water Treatment Systems Company in Jordan (Ghazal, M. 2017). This feasibility study is presented to evaluate the technical and economical aspects of mass production of the new system. In addition, the issue of modifying the existing old systems at homes by adding feeder and discharge unit, as shown in Figure 1, to utilize the use of the rejected water, while maintaining the allowable limits of Total Dissolved Solids (TDS) and water quality adequate for domestic use. This paper proves that when the new feeder and discharge unit added to an existing RO system or a new system that is used, the quality of the produced fresh drinking water does not change and remains in the acceptable specifications. In addition, the cleaning water after mixing with the rejected saline water still within specified acceptable limits of less than 500TDS.

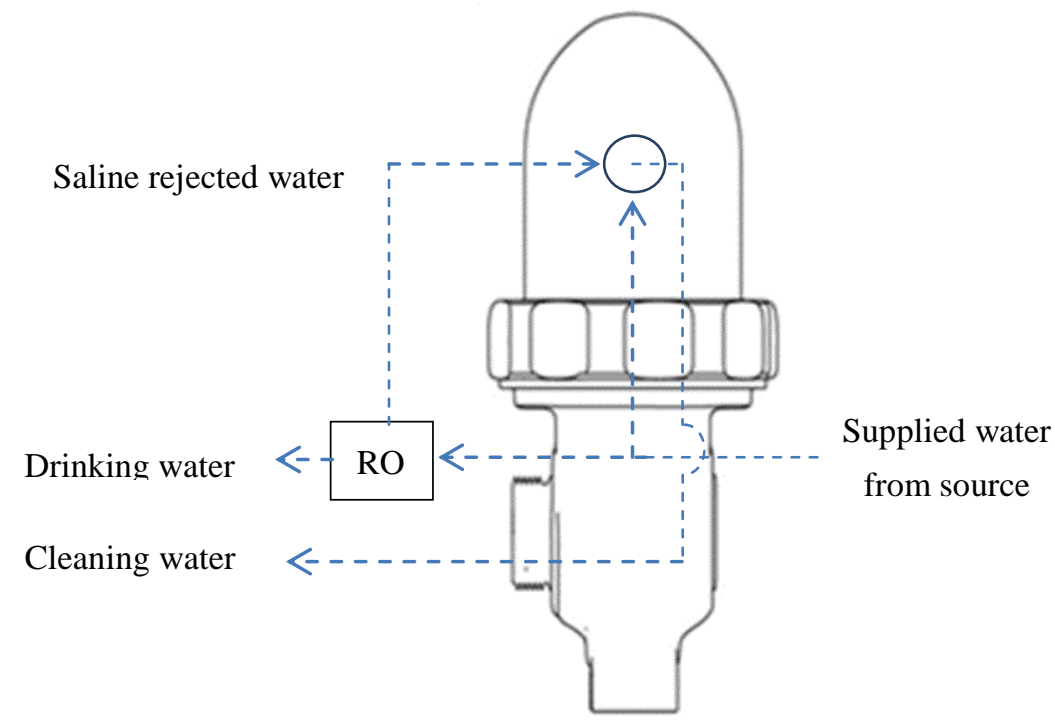

Figure 1. The main components of the feeder and discharge unit. Showing the upper mixing and the lower feeder units connected to the existing RO system. 


\section{Implementation the New RO System}

The new and modified RO system is shown in Figure 2. Initially, the RO system is viewed as a traditional RO system as shown in Figure 2 (A); the additional components added to the traditional system are shown in Figure 2 (B), these components include a feeder and discharge unit, low-pressure valve, filter for dirty water treatment and salt water tank. The purpose of this modification is to reuse the rejected saline water, with $100 \%$ water recovery. The technical operation of the system and testing the new system performance at various locations were described in details in our previous study to calculate the overall efficiency (Ghazal, M. 2017). The quality of the drinking water and the mixed cleaning water matches the acceptable limits of less than 500TDS, as listed by the American and Jordanian standards, and the produced mixed water for cleaning is safe to use (American Public Health Association, 1999).

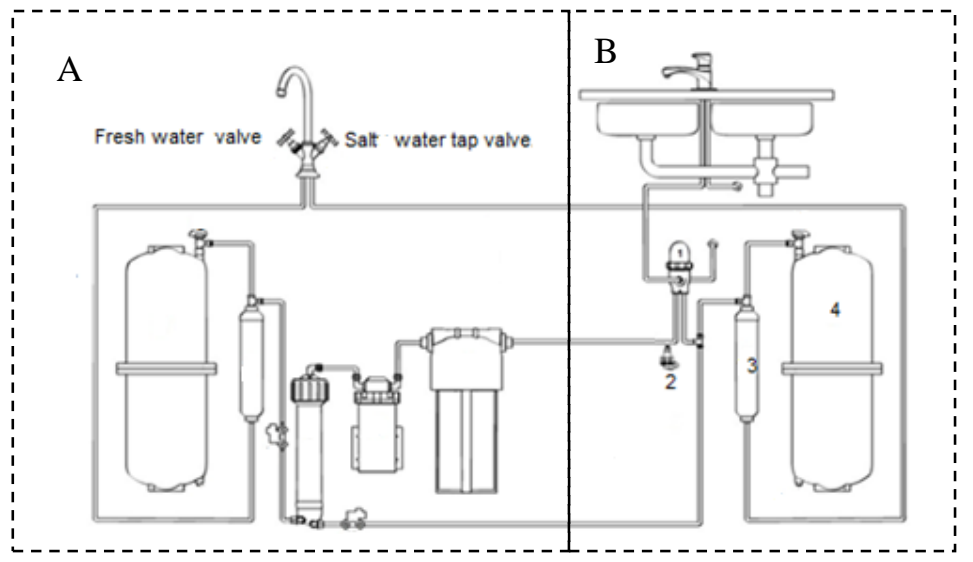

Figure 2. New RO system. (A) Components found in traditional RO system and (B) The additional component added. Numbers shown the Figure are 1. Feeder and discharge unit 2. Low-pressure valve. 3. Filter for dirty water treatment. 4. Salt water tank.

\section{History of RO Systems in Jordan}

The main two sources of fresh drinking water in Jordan are bottled water and RO systems installed in homes. It is estimated that about 125,000 RO systems are currently installed in Jordanian homes based on sales' figures that are estimated by 25,000/year (Al-Jayyousi \& Mohsen, 2001). When using a traditional RO system, five liters of wasted water are consumed for drainage purpose to produce only one liter of fresh water, approximately. Because the average family daily consumption of fresh water is about 20 liters, the wasted water from RO systems that are already installed in Jordan, is about 12,500,000 liters/day, which is equivalent to 4.5 million cubic meter a year (Ministry of Water and Irrigation, Jordan, 2009). These figures are alarming since Jordan has a Water stress index above $100 \%$ according to Fritzmann (Fritzmann ae al., 2007). In addition, this figure of wasted water to drain could be increased dramatically taking into account the RO systems installed in industrial factories and companies in Jordan that sell bottled waters. 


\subsection{Cost of Wasted Water from Installed RO Systems in Jordan}

The cost of water supplied to household is subjected to "Tariff upward" scale as set by the government as shown in Table 1 (Ministry of Water and Irrigation, Jordan, website, 2018). To estimate the cost of the wasted water from the currently installed RO systems in Jordan, in Jordanian Dinar (JD), based on the tariff supplied by the Jordanian government and considering the average of all slices tariffs, the average cost of the water bill is about $75 \mathrm{JD}$. A total of 212,359JD water quarter bills for homes using RO systems studied. For those bills, in each billing quarter the cost of the wasted water from RO system reached JD 15.5million each year. These figures signify the importance of the all-new system, which built by Petra for Water Treatment Systems Company in Jordan. Table 1 shows some samples of how water bills are calculated, detailed and the complete tariff rates are available in ministry of water and irrigation website (Ministry of Water and Irrigation, Jordan, website, 2018).

Table 1. Water and wastewater tariff for quarterly bills for residential consumption only

\begin{tabular}{|c|c|c|c|c|c|c|}
\hline $\begin{array}{l}\text { Consum. } \\
\left(\mathrm{m}^{3}\right)\end{array}$ & $\begin{array}{r}\mathrm{P} \\
\text { Water }\end{array}$ & $\begin{array}{l}\text { ice } / \mathrm{m}^{3} \\
\text { Waste Water }\end{array}$ & $\begin{array}{c}\text { Constant } \\
\text { value }\end{array}$ & $\begin{array}{c}\text { Bill value with } \\
\text { Waste Water (JD) }\end{array}$ & $\begin{array}{l}\text { Bill value without } \\
\text { Waste Water (JD) }\end{array}$ & $\begin{array}{l}\text { Reduction \% in } \\
\text { Waste Water }\end{array}$ \\
\hline 20 & 0.145 & 0.045 & 3.65 & 11.25 & 10.47 & 6.93 \\
\hline 40 & 0.5 & 0.29 & 1.65 & 19.1 & 16.44 & 13.93 \\
\hline 60 & 0.935 & 0.57 & 0.0 & 39.19 & 29.05 & 25.87 \\
\hline 80 & 1.15 & 0.795 & 0.0 & 74.81 & 51.47 & 31.20 \\
\hline 100 & 1.61 & 0.925 & 0.0 & 119.61 & 79.07 & 33.89 \\
\hline 120 & 1.61 & 0.925 & 0.0 & 170.3 & 111.27 & 34.66 \\
\hline
\end{tabular}

\section{Cost Calculations}

Annual cost calculations are based on several stages of the new RO system production. These stages include: (1) Spare parts needed for production, (2) Production of plastic components such as fresh and saline water tanks, (3) Assembly of subsystem and complete units, (4) Testing equipment and (5) Storage and shipments of final products

\subsection{Cost of Wasted Water from Installed RO Systems in Jordan}

The estimated production costs are divided into four main categories as shown in Table 2. Detailed studies were conducted to calculate the estimated cost of each category based on the production of 5,000 new RO systems and 30,000 feeder and discharge units annually. Table 2 shows the annual estimated production cost for each production cost category. As shown in Table 2, raw materials used in production occupied the highest annual estimated cost followed by the manufacturing expenses, workers' wage and then depreciations. The total annual cost was calculated to be 1,294,328 JD.

Table 2. Annual production cost

\begin{tabular}{lc}
\hline \multicolumn{1}{c}{ Main Categories } & Annual Cost (JD) \\
\hline Raw materials used in production & 925,592 \\
\hline Workers' wages & 157,800 \\
\hline Manufacturing expenses & 170,818 \\
\hline Depreciations & 39,818 \\
\hline Total & $1,294,328$ \\
\hline
\end{tabular}

Table 3 provides a summary for the annual estimated depreciations for the applicable categories related to the new RO system production. The categories that can be depreciated are the building, furniture, machines, transportation media (i.e. pallet jacks, vehicles and delivery trucks), insurance and license. According to the data shown in Table 3, the initial costs and lifespans for all categories related to the production were determined based on a detailed market study. Annual depreciation of each category was also calculated by dividing the initial cost by the lifespan (for each category). For example, the building initial cost was 130,000 JD and its life that was estimated by 20 years; then the depreciation of 
the building was calculated by dividing the cost value by the lifespan (i.e. 130,000/20=6500 JD). Based on Table 3, the total annual depreciation of this project was 39,261 JD.

Table 3. Annual fixed cost deprecations

\begin{tabular}{lccc}
\hline \multicolumn{1}{c}{ Main Categories } & Cost (JD) & Lifespan (Years) & Annual Depreciations (JD) \\
\hline Building & 130,000 & 20 & 6,500 \\
\hline Furniture & 25,800 & 10 & 2,500 \\
\hline Machines & 238,420 & 10 & 23,842 \\
\hline Transportation media & 60,000 & 10 & 6,000 \\
\hline Insurances and license & 6,776 & 20 & 339 \\
\hline Total & & & 39,181 \\
\hline
\end{tabular}

\subsection{Net Income}

Table 4 provides a summary for calculating the new RO system net annual income. The annual revenue for the new RO system was estimated by 2,359,524 JD (based on the production of 5,000 new RO systems and 30,000 feeder and discharge units, annually). The total annual production cost was 1,294,328 JD. Detailed calculations of the production cost are shown in Table 4 . The annual operation profit was calculated by subtracting the annual production cost from the total annual revenue, which resulted in having a total annual revenue 1,065,196 JD. Now, there is a running cost associated to the project including to cost of general and administrative expenses, marketing, licenses and consultation fees, sales' expenses and consumables. The total annual running cost was 480,628 JD as shown in Table 4. At the end, the annual running cost were subtracted from the operation profit to have the net annual income of 584,568 JD. This net annual income indicates a successful project.

Table 4. Net annual income

\begin{tabular}{|c|c|}
\hline Main Categories & Money in one year (JD) \\
\hline Total revenue from sale & $2,359,524$ \\
\hline Production cost & $-1,294,328$ \\
\hline Operation profit & $1,065,196$ \\
\hline \multicolumn{2}{|c|}{ Running cost subcategories (subtracted from operation profits) } \\
\hline Subcategories of Running Costs & $-203,574$ \\
\hline Marketing & $-151,558$ \\
\hline Licenses and consultation fees & $-6,776$ \\
\hline Sales' expenses & $-86,562$ \\
\hline Consumables & $-32,158$ \\
\hline Total (Running cost) & $-480,628$ \\
\hline Net Income & 584,568 \\
\hline
\end{tabular}

\subsection{Net Profit Margin and Return on Investment}

Two important indicators measure the success or the failure of feasibility studies. These are the net profit margin and the payback period indicators. To validate the proposed feasibility study of "Petra Company for Water Treatment Systems" both the net profit margin and the payback period were calculated. The net profit margin was calculated by dividing the net income by total sales revenue; based on the data shown in Tables 2 and 4, the net profit margin was equal to $(584,568 / 2,359,524=24.75 \%)$. The payback period of the project was calculated by dividing the initial investment by the cash inflow per period. This means that the payback period for this project will be $1,294,328 / 584,568=2.29$ years. The values of both indicators are promising and encouraging and could attract local investors easily. 


\section{Discussion and Conclusions}

The new modified RO system, which targeted domestic use at homes, showed significant water savings without reducing the quality of drinking water by using the reject water for cleaning purpose. Currently, the use of RO systems in both homes and industry in Jordan is in an increasing manner. This is because the quality and the quantity of the supplied water by government in Jordan are not promising for any possible improvement in the near future. Consequently, mass production of the new units is vital because the water saving Jordan is important and because the region needs. The feasibility study conducted in this paper concludes that the production of new RO units by Petra Company for Water Treatment Systems could be highly feasible. This is because of the fact that the new design of RO system built by the company in Jordan is registered in twelve countries for intellectual property rights. In addition, this system introduced to the regional countries such as the Arabian Gulf countries since these countries are also facing the same water shortages as in Jordan. The high profit margin and the short payback period of this project will attract investors as well as government support. This study can be extended in future to study different alternatives for producing fresh drinking water and compare them with the proposed new RO system that is studied here.

\section{Acknowledgments}

This research supported by a grant from the Ul-Urdonia Lil-Ebda/South Business Incubator. There are no conflicts of interest.

\section{References}

Al-haj Alia, M., Ajbara, A., Alia, E., \& Alhumaizi, K. (2013). Optimization-based periodic forcing of RO desalination process for improved performance. Desalination Water Treatment, 51, 6961-6969. https://doi.org/10.1080/19443994.2013.791767

Al-Jayyousi, O., \& Mohsen, M. (2001). Evaluation of small home use reverse osmosis units in Jordan. Desalination, 139, 237-247. https://doi.org/10.1016/S0011-9164(01)00315-0

American Public Health Association, (1999). Standard Methods for the examination of Water and Wastewater, Am. Public Health Asscn., Am. Water Works Asscn., Water Poll. Fed. 15th ed.

Avlonitis, S. A. (2002). Operational water cost and productivity improvements for small-size RO desalination plants. Desalination, 142, 295-304. https://doi.org/10.1016/S0011-9164(02)00210-2

Chaoa, Y-M., \& Liangb, T. M. (2008). A feasibility study of industrial wastewater recovery using electrodialysis reversal. Desalination, 221, 433-439. https://doi.org/10.1016/j.desal.2007.04.065

Fanga, Y., \& Duranceau, S. J. (2013). Comparison of nonhomogeneous and homogeneous mass transfer in reverse osmosis membrane processes. Desalination Water Treatment, 51, 6444-6458. https://doi.org/10.1080/19443994.2013.822170

Fritzmann, C., Löwenberg, J., Wintgens, T., Melin, T. (2007). State-of-the-art of reverse osmosis desalination. Desalination, 216, 1-76. https://doi.org/10.1016/j.desal.2006.12.009

Ghazal, M. (2017). Jordan host registered Syrian refugees. The Jordan Times. 3, 21.

Khana, H. M., Tariqa, M., Bashira, F., Shafiqa, T., Khana, R., \& Jung, J. (2013). Arsenic removal from drinking water with conventional and modified adsorbents: the factorial design of experiments. Desalination Water Treatment, 51, 7304-7310. https://doi.org/10.1080/19443994.2013.797458

Kolodziejski, J., \& Gasson, C. (2005). Desalination markets 2005-2015: A global assessment and forecast. Global Water Intelligence. June 2005.

Lauren, F., Greenleea, Desmond, F., Lawlerb, Benny, D., Freemana, Benoit Marrotc, \& Philippe Moulinc. (2009). Reverse osmosis desalination: Water sources, technology, and today's challenges. Water research, 43, 2317 - 2348. https://doi.org/10.1016/j.watres.2009.03.010

Middle East Desalination Research Centre (2009). Watermark newsletter. 28, 1-12.

Ministry of Water and Irrigation, Jordan (2018). Retrieved from http://www.mwi.gov.jo/sites/ar-jo/default.aspx

Ministry of Water and Irrigation. Amman, Jordan (2009). Annual report, Water Authority of Jordan. 2009.

Mostafa, A., \& El-Aassar, A. (2013) Improvement of reverse osmosis performance of polyamide thin-film composite membranes using $\mathrm{TiO}_{2}$ nanoparticles. Desalination Water Treatment, 55, 1-12.

Qasim, T., Abu-Haifa, A., \& Abu-Haifa, M. (2016). Design and performance of a new zero-wastewater small size reverse osmosis desalination system. Desalination and Water Treatment, 5712, 5385-5390.

https://doi.org/10.1080/19443994.2014.1003980 
Sassi, K., \& Mujtaba, I. (2012). Optimal operation of RO system with daily variation of freshwater demand and seawater temperature. Computer Aided Chemical Engineering, 30, 817-821. https://doi.org/10.1016/B978-0-444-59520-1.50022-1

Young, H. L., Huang, C., \& Te Lin, J. C. (2010). Seasonal fouling on seawater desalination RO membrane. Desalination, 250, 548-552. https://doi.org/10.1016/j.desal.2009.09.021

Zaleschi, C., Sáez, P., Cañizares, I. Cretescu, \& Rodrigo, M. A. (2013). Electrochemical coagulation of treated wastewaters for reuse. Desalination and water treatment, 51, 3381-3388. https://doi.org/10.1080/19443994.2012.749192

Zhang, X. Q., Xu, J. F., Du, M. X., \& Zhang, Y. (2011). Boiler-Water Treatment by Reverse Osmosis Employing Solar Energy. Advanced Material Research, 374 - 377, 1021-1024. https://doi.org/10.4028/www.scientific.net/AMR.374-377.1021

\section{Copyrights}

Copyright for this article is retained by the author(s), with first publication rights granted to the journal.

This is an open-access article distributed under the terms and conditions of the Creative Commons Attribution license (http://creativecommons.org/licenses/by/4.0/). 